\title{
The Study of Shadowing Exercise on Improving Oral English Ability for Non-English Major College Students
}

\author{
Xiaolin Wang \\ College of Science, Engineering University of PAP, Xi'an 710086, China \\ 735539852@qq.com
}

Key words: Shadowing Exercise; Non-English major college students; Oral ability

\begin{abstract}
Based on the SPSS results of the oral performance of 40 non-English major college students in an impromptu speech about a given topic, this empirical study focused on the effect of shadowing exercise on improving oral ability for non-English major college students. The shadowing exercise was employed in the experimental group to make students practice repeatedly while the traditional teaching mode focusing on explanation, discussion and some oral practice was employed in the control group. The results indicated that the improvement of fluency in the experimental group was more significant. The shadowing exercise can enhance the oral ability substantially and it can be applied in college English teaching, especially in Viewing-Listening-and-Speaking teaching.
\end{abstract}

\section{Introduction}

The College English Curriculum Requirements issued by the Ministry of Education in July 2007 clearly stated that the teaching objective of college English is to cultivate students' comprehensive English ability, especially the listening and speaking ability, to make them communicate effectively in their future study, work and social activities, to enhance their autonomous learning ability and comprehensive cultural literacy as well, and to meet the needs of social development and international communication of China[1]. In China, college students' oral English ability has been a long-term problem since most of them have been learning English for more than 10 years, they still can't communicate in English. In order to meet social demands for oral English abilities, the CET (College English Test) Committee has carried out major reforms to add the oral test in CET4 and CET6 since June, 2016, indicating the urgency of improving college students' oral English ability and its importance in the overall development of college English education.

This paper analyzed the current situation of non-English major college students' oral English abilities and its reasons. Through the empirical research, the shadowing exercise's influence on improving oral English ability has been explored and its effectiveness in oral English teaching has been proved.

\section{Shadowing Exercise}

Shadowing exercise, a language learning technique developed by the American Professor Alexander Arguelles, which means learners attempt to repeat--to "shadow" -- what they hear as quickly and accurately as they hear it. Since early 1980s, it has been applied to the English teaching in China and has acquired a great of achievements. Ye Guigang(1983) pointed out that the shadowing exercise requires learners speak while listening and they should strive to keep up with the speed of the recording, almost making the sounds at the same time. Learners must be highly focused and agilely make corresponding responses through imitating pronunciation loudly, which contains both the information input and output processes [2].In practice, the speed of shadowing is 2 seconds slower that of broadcasting while ensuring that the speed and content of shadowing are consistent. According to Lambert, shadowing exercise technically is a rhythmic acoustic tracking task that requires the practicer to make instant sounds to the sound stimulus signal [3].

These definitions reflect the close relationship between the shadowing exercise and the listening 
and speaking ability. In recent years, many studies have shown that the shadowing exercise can improve learners' English imitation ability, ability of thinking, memory ability, and sense of English, However, its effect on improving the oral English ability has seldom been studied. Because the shadowing exercise integrates listening, thinking and speaking, combined with relevant theories and the simultaneous interpretation mode proposed by the famous interpretation expert Daniel Gile, SI $=\mathrm{L}+\mathrm{M}+\mathrm{P}$, in which SI = Simultaneous interpretation, $\mathrm{L}=$ Listening + Analysis (focusing on analyzing and understanding what you hear), $\mathrm{M}=$ Short-term memory (storing what you hear in your memory), $\mathrm{P}=$ Production (translating and conveying the stored information) [4], the shadowing exercise mode can be concluded as $\mathrm{SE}=\mathrm{L}+\mathrm{M}+\mathrm{S}$, $\mathrm{SE}=$ Shadowing exercise, $\mathrm{L}=$ Listening + Analysis, $\mathrm{M}=$ Short - term memory, $\mathrm{S}=$ Speaking, so its final step and objective is oral production.

\section{Analysis of the current situation of non-English major college students' oral English ability and its reasons.}

From the teaching practice and research, the author found that cultivation of college students' oral English ability was seriously lagged behind. Less than 30\% non-English major students were able to speak fluently on general topics and to express personal views with correct pronunciations and intonations. $50 \%$ of them could only say simple sentences with grammatical mistakes and frequent incorrect pronunciations and intonations. The rest of them can only say few relevant words, phrases or even completely unable to speak [5]. The main reasons are as follows.

1) In the current college English teaching, most universities regard the passing rate of CET4 and CET6 as a key indicator, closely related to degrees. Since the oral test was not included in the CET system before June 2016; few measures had been taken to improve students' oral English ability.

2) In college English course system, no enough attention has been paid to oral English teaching. English courses are basically divided into intensive reading (or reading, writing and translation) and listening (listening and speaking), in which 1/3 should be the listening classes. But actually, it is less than $1 / 3$ due to the lack of faculty, limitation of teaching scales and teaching conditions.

3) There is a serious lack of language communication environment. Non-English major students seldom communicate in English, and the classroom is the major place to learn, but it is restricted by period, class size, the limitation of students' English level, etc. The class provides neither sufficient language input nor enough opportunities for students' language output.

\section{The experiment of shadowing exercise in oral English training}

In order to find out effective and efficient methods to improve students' oral English ability, through the empirical research, this paper studied the shadowing exercise's influence on improving students' oral English ability from the aspect of fluency. and explored its effectiveness in college oral English teaching.

\subsection{Experimental hypothesis}

The hypothesis of statistical significance is that shadowing exercise can significantly improve the oral English fluency of non-English major college students.

\subsection{Subjects}

Selected 40 students (28 boys, 12 girls) randomly from the author's two classes. All of them were sophomores in the Engineering University of PAP and they had similar English learning background with no obvious difference in English levels. All 40 participants were randomly divided into two groups - the experimental group and the control group, 20 students for each group.

\subsection{Experimental tools}

The pre-class and post-class questionnaire.The purpose of pre-class questionnaire survey was to collect subjects' general information of oral English, including interest in oral English, the recognition of the importance of oral English, the frequency of oral English practice, the time spent 
on oral English and the understanding of shadowing exercise. The subjects were all 40 participants. The post-class questionnaires were mainly used to know the training effect of shadowing exercise, including interest in shadowing exercise, interest changes in oral English, changes in oral English fluency and English sense, its influence on improving oral English and whether they would use shadowing exercise in future English learning. The questionnaire adopted the LIKERT 5 scale form.

The teaching materials. Teaching and training materials in class and post-class were mainly selected from The Intermediate Course of Interpretation (Shanghai: Shanghai foreign language education press) and VOA Special English. The training difficulty increased gradually, from shadowing simple sentences at first to difficult and long sentences and paragraphs finally. The shadowing time stayed at 1-2 minutes initially, and gradually increased to 2-3 minutes. The oral discussion materials in class and the oral test before and after the experiment came from the New Horizon College English -Viewing-Listening -Speaking 3(the 3rd edition).

Statistical tools. The tool was statistical software SPSS18.0.

\subsection{Experiment implementation}

The experiment began with a questionnaire survey and an oral test in April, 2017. The classroom teaching was from May 10 to July 12, 10 weeks in total, 1 period (1 hour) each week for each group, namely, 10 periods for the experimental group and the control group respectively on every Wednesday. The two groups were completely consistent in learning materials, topics and schedules, and the classes were mainly carried out in two forms: a. Listen to news, story, dialogue, etc. and repeat the content. b. Students discussed topics or scenes given by the teacher to make a speech. The first method was mainly used in the early stage, while later two methods were used in combination. However, differences existed in their teaching methods. The experimental group integrated the shadowing exercise into the teaching completely, with shadowing exercise and the oral expression as the main; The control group adopted the traditional teaching mode, with no shadowing, and the oral expression of the students was only a small part. For example, the concrete teaching implementation method was shown in table 1.

At the same time, 40 students were required to review and practice each day after class, and the experimental group should record the after-class shadowing. When all classes finished, 40 subjects would have an oral test of making an impromptu speech on environmental problems (New Horizon College English: Viewing, Listening and Speaking 3) in a relaxed environment, without knowing anything in advance. Both the pre-experiment and post-experiment oral test were recorded as a basis for data analysis.

\subsection{Data collection and statistics}

It mainly included the collection and analysis of questionnaires and the statistical analysis of two groups' oral test scores before and after the experiment. All pre-class and post-class questionnaires were collected and all were valid. The oral test aimed to exam the oral English fluency. Fluency is measured by the number of words spoken per minute [6]. （Skehan and Foster,1999)

\section{The statistical analysis of results.}

\subsection{Results of questionnaires}

According to the pre-experiment questionnaire survey of 40 subjects, before the experiment, 31 (77.5\%) students thought oral English was very important; 21 (52.5\%) students were interested in oral English; only 6 (15\%) students consciously practiced oral English but it was not more than 30 minutes; and 35 (87.5\%) students had never heard of shadowing exercise.

The post-experiment questionnaire survey of 20 subjects in the experimental group showed that after the experiment 18 (90\%) students thought the shadowing exercise was interesting. 19 (95\%) students said their oral English fluency had been greatly improved. 20 (100\%) students all thought their oral English ability had been enhanced. 17 (85\%) students believed the shadowing improved their confidence and interest in speaking. And 17 (85\%) students said they would continue to use the shadowing exercise to practice oral English in the future. From all above, the shadowing 
exercise exerted a positive effect on improving oral English ability.

Table 1 Experimental procedures (60 minutes)

\begin{tabular}{|c|c|c|}
\hline & experimental group & control group \\
\hline Step1 & Lead-in (2min) & Lead-in (2min) \\
\hline Step2 & $\begin{array}{l}\text { Students listened to the learning } \\
\text { content thoroughly to seek out the main } \\
\text { idea of teaching materials and the } \\
\text { teacher explained new vocabulary } \\
\text { briefly.(5min) }\end{array}$ & $\begin{array}{l}\text { Students listened to the content } \\
\text { and answered questions. And then } \\
\text { the teacher explained new } \\
\text { vocabulary in detail, asked } \\
\text { students to read after the teacher, } \\
\text { made sentences by using new } \\
\text { words and explained the key and } \\
\text { difficult points to students. } \\
\text { (23min) }\end{array}$ \\
\hline Step3 & $\begin{array}{l}\text { Conducted shadowing exercise: the } \\
\text { whole process was from easy to } \\
\text { difficult. Students looked at the text to } \\
\text { shadow it sentence by sentence at first. } \\
\text { After practicing several times, students } \\
\text { started to shadow several sentences and } \\
\text { finally the whole text without looking } \\
\text { at it. Shadowing speed was from slow } \\
\text { to fast. In the shadowing process, } \\
\text { students should pay attention to imitate } \\
\text { pronunciation, intonation, tone, etc., } \\
\text { and mark difficulties to imitate them } \\
\text { repeatedly. The teacher offered } \\
\text { immediate guidance and help. After } \\
\text { shadowing exercise, some students have } \\
\text { been able to memorize the } \\
\text { content.(30min) }\end{array}$ & $\begin{array}{l}\text { The teacher let students look at the } \\
\text { text to read it repeatedly.(10min) }\end{array}$ \\
\hline Step4 & $\begin{array}{l}\text { The teacher asked students to read } \\
\text { aloud and corrected the pronunciation, } \\
\text { and also asked students to correct each } \\
\text { other.(10min) }\end{array}$ & $\begin{array}{l}\text { The teacher asked students to read } \\
\text { and corrected the } \\
\text { pronunciation. }(5 \mathrm{~min})\end{array}$ \\
\hline Step5 & $\begin{array}{l}\text { Some students repeated the text and } \\
\text { others listened, summarized and } \\
\text { assimilated the content. (10min) }\end{array}$ & $\begin{array}{l}\text { Let students summarize the text } \\
\text { and assimilate it. (5min) }\end{array}$ \\
\hline Step6 & Summary and assignments(3min) & $\begin{array}{l}\text { Students repeated the text } \\
\text { initiatively }(10 \mathrm{~min})\end{array}$ \\
\hline Step7 & & $\begin{array}{l}\text { Let students listen to the tape } \\
\text { again; summarized and assigned } \\
\text { homework }(5 \mathrm{~min})\end{array}$ \\
\hline
\end{tabular}

\subsection{Oral test results}

In order to study the shadowing exercise's influence on oral English teaching, the author analyzed the pre-experiment and post-experiment oral test scores of both groups through SPSS. The test score of each subject was the number of words spoken by the subject per minute. And before the experiment, t-test on the oral test scores of two groups was carried out. The results were shown in table 2. 
Table 2 The homogeneity test on the pre-experiment oral test scores of two groups

\begin{tabular}{|c|c|c|c|c|c|c|c|c|}
\hline \multirow{2}{*}{ variable } & \multicolumn{3}{|c|}{ The experiment group } & \multicolumn{3}{|c|}{ The control group (20) } & \multirow{2}{*}{ T } & \multirow{2}{*}{ P ( Sig) } \\
\cline { 2 - 7 } & $\mathrm{M}$ & $\mathrm{SD}$ & $\mathrm{SE}$ & $\mathrm{M}$ & $\mathrm{SD}$ & $\mathrm{SE}$ & & \\
\hline Fluency & $\begin{array}{c}46.400 \\
0\end{array}$ & $\begin{array}{c}11.5822 \\
0\end{array}$ & 2.58986 & 47.1000 & 11.42896 & 2.55559 & -.192 & .848 \\
\hline
\end{tabular}

It can be seen from the above table that the average score of the experimental group was 46.4000 , which was slightly lower than that of the control group on average of 47.1000. $\mathrm{T}=-.192, \mathrm{P}=.848$ $(\mathrm{P}>.05)$, that is, there was no significant difference in oral English fluency between the experimental group and the control group before the experiment. The results indicated the pre-experiment test scores of the two groups had homogeneity, and the selected samples could be used as the research subjects. The oral English fluency of both groups after the experiment was shown in table 3.

It can be seen from the above table that, after the experiment, the average score of oral fluency of the experimental group was 71.8000, which was significantly higher than that of the control group with an average of 57.4000. The average score of the experimental group increased by 25.4000, which was much higher than that of the control group of 10.3000 . And Sig $=.001<<.05$, which indicates significant differences. Meanwhile, there was no 0 value between the upper and lower limits, also indicating the significant difference between the two groups, which was statistically significant. The above experimental data revealed that the oral English fluency of the experimental group had been improved greatly, therefore the shadowing exercise can improve the oral English ability of non-English major college students significantly.

Table 3 The results analysis of oral fluency after the experiment

\begin{tabular}{|c|c|c|c|c|}
\hline \multicolumn{5}{|c|}{ Group Statistics } \\
\hline Groups & $\mathrm{N}$ & $\mathrm{M}$ & $\mathrm{SD}$ & $\mathrm{SE}$ \\
\hline
\end{tabular}

\begin{tabular}{|c|c|c|c|c|c|c|c|c|c|c|c|}
\hline \multicolumn{12}{|c|}{ Independent Samples Test } \\
\hline & & \multicolumn{2}{|c|}{$\begin{array}{c}\text { Levene's Test } \\
\text { for Equality of } \\
\text { Variances }\end{array}$} & \multicolumn{8}{|c|}{ t-test for Equality of Means } \\
\hline & & \multirow[t]{2}{*}{$\mathrm{F}$} & \multirow[t]{2}{*}{ Sig. } & \multirow[t]{2}{*}{$\mathrm{t}$} & \multirow[t]{2}{*}{$\mathrm{df}$} & \multirow{2}{*}{$\begin{array}{c}\text { Sig. } \\
\text { (2-tailed) }\end{array}$} & \multirow{2}{*}{$\begin{array}{c}\text { Mean } \\
\text { Difference }\end{array}$} & \multirow{2}{*}{$\begin{array}{l}\text { Std.Error } \\
\text { Difference }\end{array}$} & \multicolumn{3}{|c|}{$\begin{array}{c}\text { 95\% Confidence Interval } \\
\text { of the Difference }\end{array}$} \\
\hline & & & & & & & & & Lower & & Upper \\
\hline \multirow{2}{*}{$\begin{array}{c}\text { Test } \\
\text { scores of } \\
\text { oral } \\
\text { English } \\
\text { fluency }\end{array}$} & $\begin{array}{l}\text { Equal variances } \\
\text { assumed }\end{array}$ & \multirow{2}{*}{.200} & \multirow{2}{*}{.658} & 3.616 & 38 & .001 & 14.40000 & 3.98220 & 6.33846 & \multicolumn{2}{|c|}{22.46154} \\
\hline & $\begin{array}{c}\text { Equal variances } \\
\text { not assumed } \\
\end{array}$ & & & 3.616 & 37.527 & .001 & 14.40000 & 3.98220 & 6.33513 & & 22.46487 \\
\hline \multirow{2}{*}{\multicolumn{4}{|c|}{$\begin{array}{c}\text { Results of oral English } \\
\text { fluency }\end{array}$}} & \multicolumn{3}{|c|}{$\begin{array}{l}\text { The experiment } \\
\text { group }\end{array}$} & 20 & 71.8000 & \multicolumn{2}{|c|}{12.28077} & 2.96967 \\
\hline & & & & \multicolumn{3}{|c|}{ The control group } & 20 & 57.4000 & \multicolumn{2}{|c|}{11.86503} & 2.65310 \\
\hline
\end{tabular}

\section{Conclusion}

Through empirical study, this paper analyzed showing exercise's influence on improving non-English major college students' oral English ability. The research results showed that shadowing exercise can improve their oral English ability. The students' fluency of oral English has been greatly improved. Their oral English pronunciation and intonation also has been improved 
obviously. Students' interest in oral English was stronger and confidence was strengthened. Therefore, the author suggests that in college English teaching, especially in the Viewing-Listening-and-Speaking course, teachers should consciously employ the shadowing exercise to strengthen students' oral English ability. Materials such as VOA special news, film dialogue or interview can be used to improve students' interest. In terms of shadowing speed, the natural speed is ideal, but it could be adjusted based on students' levels. Shadowing content could be from easy to difficult and shadowing time is extended gradually. At the same time, when students cannot understand certain words, the teacher should remind students to keep up with the record. Teachers should play the leading role in the shadowing exercise, fully arouse students' enthusiasm on oral English, and finally improve the students' oral ability through repeated practice.

\section{References}

[1] Department of Higher Education of the Ministry of Education. Teaching requirements for college English courses. [M]. Shanghai: Shanghai foreign language education press, 2007

[2] YE Guigang. Discussion on the Rapid Shadowing Approaches [J]. College English, 1983(1).

[3] Lambert,S. Aptitude Testing for Simultaneous Interpretation at the University of Ottawa[A]. Mcta: Translators’ Journal, 1991(36):586-594.

[4]TU Wen-ting, LIU Jin. Applied Research of Shadowing Exercise in College English Listening Comprehension Teaching $[\mathrm{J}]$. The academic journal of Anhui Polytechnic University (Social science edition),2011, 28(4):92.

[5] JIANG Qian. Extended Effects of Shadowing Exercise on Foreign Language-With Reference to Interpretation Trainees[D]. Shanghai: Shanghai International Studies University, 2013

[6] Skehan, P. and Foster, P. The influence of task structure and processing conditions on narrative retellings[J].Language Learning, 1999, 49(1): 93-120

[7] LIN Yinglan. Application Study of Shadowing in Advanced Chinese Listening and Speaking Lessons[D].Shandong: Shangdong Normal University, 2013 